\title{
Sikap Entrepreneur Mahasiswa Pendidikan Biologi
}

\author{
Agus Muliadi \\ Pendidikan Biologi, Universitas Pendidikan Mandalika \\ agusmuliadi@ikipmataram.ac.id
}

\begin{abstract}
Abstrak: Kualitas lulusan pendidikan di Indonesia harus mendapatkan perhatian serius, karena data Badan Pusat Stastistik (BPS) menunjukkan bahwa lulusan pendidikan di Indonesia masih menyumbang angka pengangguran yang cukup tinggi termasuk lulusan pendidikan tinggi. Salah satu faktor penyebabnya adalah rendahnya keterampilan (life skill) yang dimiliki oleh setiap lulusan lembaga pendidikan termasuk perguruan tinggi. Perguruan tinggi memerlukan kurikulum yang link and match dengan kebutuhan dunia kerja dan berorientasi kecakapan hidup (life skill). Sikap dan keterampilan entrepreneur diperlukan oleh setiap lulusan pendidikan tinggai agar dapat menciptakan kreativitas dan inovasi. Tujuan penelitian ini adalah untuk mengetahui (1) deskripsi sikap entrepreneur mahasiswa Pendidikan Biologi berdasarkan tingkat semester; (2) hubungan antara tingkat semester dengan sikap entrepreneur mahasiswa Pendidikan Biologi. Penelitian ini merupakan penelitian ex post facto dengan pendekatan deskriptif kuantitatif dan deskriptif korelasional. Sampel penelitian ini adalah seluruh mahasiswa Pendidikan Biologi FSTT UNDIKMA sebanyak 114 orang. Instrumen yang digunakan adalah angket tertutup dengan skala likert. Teknik analisis adalah menggunakan statistik deskriptif dan statistik inferensial uji korelasi product moment $\left(\mathrm{r}_{\mathrm{xy}}\right)$ dan dibantu dengan software SPSS 16 for windows. Hasil penelitian ini adalah (1) nilai sikap entrepreneur mahasiswa semester VIII adalah yang terbaik dengan rata-rata sebesar 3,43 dengan kategori Baik; (2) Hasil uji korelasi product moment $\left(\mathrm{r}_{\mathrm{xy}}\right)$ bahwa nilai signifikansi sebesar 0,003 lebih kecil dari nilai alpha pengujian $0,05(<0,05)$, sehingga dapat disimpulkan bahwa ada hubungan yang signifikan antara tingkat semester mahasiswa dengan sikap entrepreneur.
\end{abstract}

Kata kunci: sikap entrepreneur, mahasiswa

\section{PENDAHULUAN}

\section{Pembangunan pendidikan nasional} ditujukan untuk mewujudkan cita-cita kemerdekaan bangsa Indonesia khususnya dalam upaya mencerdaskan kehidupan bangsa sehingga akan menjadi bangsa yang beradab dan dapat bersaing di dunia Internasional. Hal ini mengharuskan seluruh jenjang dan jenis pendidikan di Indonesia harus memiliki konsekuensi yang sama yaitu bermuara kepada tujuan pendidikan nasional untuk mengembangkan sumber daya manusia secara terarah, terpadu, dan menyeluruh dengan melalui berbagai upaya proaktif dan reaktif oleh seluruh komponen yang ada secara optimal sesuai dengan potensinya dalam membentuk manusia Indonesia seutuhnya. Perkembangan ilmu pengetahuan dan teknologi yang didukung oleh arus globalisasi saat ini memunculkan persaingan dalam berbagai bidang kehidupan. Hal ini mewajibkan lulusan dunia pendidikan yang akan mencetak lulusan yang kreatif, inovatif, handal, berkualitas dan siap bersaing di berbagai bidang kehidupan (Fatimah, 2013; Primandaru, 2017).

Lulusan pendidikan di Indonesia saat ini menyumbang angka pengangguran yang cukup tinggi. Badan Pusat Statistik (BPS) melaporkan bahwa Tingkat Pengangguran Terbuka (TPT) di Indonesia per Februari 2018 berjumlah 6,87 juta orang atau 5,13\%. Pengguran yang lulusan pendidikan Sekolah Dasar (SD) ke bawah sebesar 2,67\%, lulusan Sekolah Menengah Pertama (SMP) sebesar $5,18 \%$, lulusan Sekolah Menengah Atas (SMA) sebesar 7,19\%, lulusan Sekolah Menengah Kejuruan (SMK) sebesar 8,92\%, lulusan Diploma I-III sebesar 7,92\% dan lulusan Sarjana sebesar 6,31\%.

Pengangguran lulusan perguruan tinggi cukup besar yaitu Diploma 7,92\% dan Sarjana $6,31 \%$. Fenomena ini sangat memperihatinkan dan sekaligus menjadi 
tantangan bagi lembaga pendidikan tinggi untuk meningkatkan kualitas lulusannya. Perguruan tinggi tidak hanya bertugas melahirkan banyaknya lulusan, akan tetapi yang terpenting adalah seberapa baik kualitas dan tingkat berkontribusi lulusan dalam kehidupan masyarakat dan mampu menghadapi tantangan global. Oleh sebab itu, lulusan perguruan tinggi harus memiliki kompetensi minimal, sikap profesional, kreatif, inovatif, produktif, dan adaptif.

$$
\text { Menurut Porter (1997) (dalam }
$$

Wahyuni dan Hidayati, 2017), perguruan tinggi memerlukan kebijakan pengembangan berbasis masyarakat luas (Broad Based Education) dan berorientasi pada kecakapan hidup (life skill). Perguruan tinggi diharapkan untuk mengembangkan kurikulum dan pembelajaran yang tidak hanya berorientasi pada keilmuan semata, namun juga dapat memfasilitasi kecakapan hidup (life skill) bagi lulusannya. Setiap lulusan perguruan tinggi diharapkan memiliki kompetensi tambahan yang dapat menopang kecakapan hidupnya. Kompetensi kewirausahaan (entrepreneur) diyakini efektif untuk meningkatkan kemandirian seseorang, sehingga diperlukan adanya pembelajaran kewirausahaan diterapkan dalam kurikulum perguruan tinggi. Pembelajaran kewirausahaan dapat merubah persepsi, sikap dan prilaku mahasiswa untuk memiliki motivasi kuat dalam menciptakan kreativitas dan inovasi demi terwujudnya wirausaha handal (Suryana, 2014). Pemerintah secara resmi menganjurkan pendidikan tinggi untuk dapat mengintegrasikan pembelajaran kewirausahaan (entrepreneur) dalam kurikulum dan pembelajarannya, sehingga dapat dihasilkan lulusan yang kompeten di bidang entrepreneur. Lulusan yang memiliki sikap dan keterampilan wirausaha (entrepreneur) diyakini memiliki kecakapan hidup dan kemandirian yang lebih baik serta kompetitif. Hal itu sesuai dengan pendapat Agusti, (2017) yang menyatakan bahwa pentingnya memiliki sikap wirausaha (entrepreneur) karena orang yang memiliki kemampuan tetapi tidak memiliki kemauan dan orang yang memiliki kemauan tetapi tidak memiliki kemampuan, keduanya tidak akan menjadi seorang wirausahawan yang sukses.

Kurikulum Program Studi Pendidikan Biologi Universitas Pendidikan Mandalika (UNDIKMA) telah memasukkan kewirausahaan menjadi salah satu matakuliah yang wajib ditempuh oleh mahasiswa. Keberadaan matakuliah kewirausahaan menunjukkan komitmen awal yang cukup baik untuk mengembangkan sikap dan keterampilan kewirausahaan (entrepreneur) bagi setiap lulusannya. Pembelajaran kewirausahaan yang masih terbatas pada satu matakuliah dengan kredit hanya 2 SKS tentunya belum maksimal karena pengembangan sikap dan keterampilan wirausaha (entrepreneur) secara komprehensif memerlukan waktu dan pengalaman yang berulang-ulang, terstruktur dan berjenjang. Oleh sebab itu, diperlukan adanya pemetaan untuk mengetahui tingkat sikap berwirausaha (entrepreneur) mahasiswa Pendidikan Biologi dan perbedaan sikap berwirausaha (entrepreneur) berdasarkan jenjang semesternya. Penelitian ini bertujuan untuk mengetahui (1) deskripsi sikap entrepreneur mahasiswa Pendidikan Biologi berdasarkan tingkat semester; (2) hubungan antara tingkat semester dengan sikap entrepreneur mahasiswa Pendidikan Biologi.

\section{METODE PENELITIAN}

Penelitian ini merupakan penelitian $e x$ post facto dengan pendekatan deskriptif kuantitatif dan deskriptif korelasional. Penelitian ex post facto adalah untuk meneliti hubungan sebab akibat yang tidak dimanipulasi atau tidak diberikan perlakukan oleh peneliti, namun peneliti hanya merekam data dari kegiatan yang sudah terjadi. Kajian deskriptif kuantitatif digunakan untuk mendeskripsikan nilai sikap entrepreneur mahasiswa Pendidikan Biologi, sedangkan deskriptif korelasional digunakan untuk mendeskripsikan hubungan antara tingkat semester dengan sikap entrepreneur mahasiswa (Ibnu, 2003; Arikunto, 2006; Singarimbun, 2006). Secara operasional rancangan korelasional terdiri atas dua variabel yaitu Tingkat Semester Mahasiswa 
(X) dan Sikap Entrepreneur (Y) seperti yang disajikan pada gambar 1 berikut:

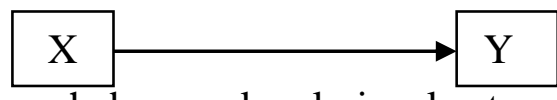

Gambar 1. Bagan hubungan korelasional antara Variabel Tingkat Semester Mahasiswa (X) dengan Sikap Entrepreneur (Y)

Penelitian ini menggunakan sampel 56 mahasiswa Pendidikan Biologi UNDIKMA yang ditentukan dengan teknik purposive sampling dengan rincian semester II sebanyak 10 orang, semester IV sebanyak 20 orang, semester VI sebanyak 16 orang, dan semester VIII sebanyak 10 orang. Intrumen yang digunakan adalah angket tertutup dengan jawaban sikap yang berdegradasi sesuai skala likert. Instrumen sikap entrepreneur yang diukur dalam penelitian ini mengacu pada indikator sikap entrepreneur yang dikembangkan Alma (dalam Agusti, 2017) yaitu percaya diri, berani mengambil resiko, kepemimpinan, kreatif dan inovatif, tekun, bertanggungjawab, berorientasi ke masa depan. Angket disusun dan diuji validitasnya oleh para pakar (expert).

Analisis data penelitian yang digunakan adalah statistik deskriptif dan statistik inferensial. Statistik deskriptif digunakan untuk mendeskripsikan sikap entrepreneur mahasiswa. Rata-rata data sikap entrepreneur dilakukan konversi dalam bentuk kategori dengan mengacu pada kategori penilaian sikap yang dikembangkan Kementerian Pendidikan dan Kebudayaan tahun 2013 yaitu:

Tabel 1. Konversi skor sikap entrepreneur mahasiswa

\begin{tabular}{|l|l|}
\hline Rata-rata skor & Interpretasi \\
\hline $3,51-4,00$ & Sangat Baik \\
$2,51-3,50$ & Baik \\
$1,51-2,50$ & Cukup Baik \\
$1,00-1,50$ & Kurang Baik \\
\hline
\end{tabular}

Statistik inferensial yang digunakan untuk mengetahui hubungan tingkat semester mahasiswa dengan sikap entrepreneur. Teknik analisis yang digunakan adalah uji korelasi product moment $\left(\mathrm{r}_{\mathrm{xy}}\right)$ pada taraf signifikansi $5 \%$, dengan rumusan hipotesis statistik yaitu $\mathrm{H} 0: \mu 1=\mu 2$ (tidak ada hubungan signifikan antara tingkat semester mahasiswa terhadap sikap entrepreneur) dan H1 : $\mu 1 \neq \mu 2$ (ada hubungan signifikan antaran dengan semester mahasiswa dengan sikap entrepreneur). Jika hasil analisis signifikan atau $p$-value uji korelasi lebih kecil dari 0,05, maka H0 ditolak dan H1 terima atau sebaliknya. Analisis data dibantu dengan software SPSS 16 for windows. Untuk menginterpretasikan nilai indeks korelasional antara varibel $\mathrm{X}$ dengan $\mathrm{Y}$, maka digunakan konversi yang diadaptasi dari Sudijono (2009) berikut ini.

Tabel 2. Interpretasi koefisien korelasi

\begin{tabular}{|ll|}
\hline Koefisien korelasi (r) & Interpretasi \\
\hline $0,00-0,199$ & Korelasi sangat lemah atau sangat rendah \\
$0,20-0,399$ & Korelasi lemah atau rendah \\
$0,40-0,599$ & Korelasi sedang atau cukup \\
$0,60-0,799$ & Korelasi kuat atau tinggi \\
$0,80-1,00$ & Korelasi sangat kuat atau sangat tinggi \\
\hline
\end{tabular}

\section{HASIL DAN PEMBAHASAN}

Instrumen untuk mengukur sikap kewirausahaan (entrepreneur) diberikan kepada mahasiswa Pendidikan Biologi Universitas Pendidikan Mandalika (UNDIKMA) semester II sebanyak 10 orang, semester IV sebanyak 20 orang, semester VI sebanyak 16 orang, dan semester VIII sebanyak 10 orang. Instrumen dikembangkan merujuk pada indikator sikap entrepreneur yang diadaptasi dari teori sikap entrepreneur yang dikembangkan teori Alma (dalam Agustis, 2017) yaitu percaya diri, berani mengambil resiko, kepemimpinan, kreatif dan inovatif, tekun, bertanggungjawab, berorientasi ke masa depan. Hasil uji validitas oleh para pakar (expert) sebagai validator menunjukkan bahwa instrumen sikap entrepreneur secara kualitatif dinyatakan valid.

Deskripsi data hasil pengukuran sikap entrepreneur mahasiswa disajikan pada tabel 3 berikut ini:

Tabel 3. Data sikap entrepreneur mahasiswa

\begin{tabular}{|c|c|c|c|}
\hline Semester & Total Skor & Rata-Rata & Kategori \\
\hline II & 30,17 & 3,02 & Baik \\
\hline IV & 62,83 & 3,14 & Baik \\
\hline VI & 53,50 & 3,34 & Baik \\
\hline VIII & 34,33 & 3,43 & Baik \\
\hline
\end{tabular}


Deskripsi data hasil pengukuran pada tabel di atas menunjukkan data sikap entrepreneur mahasiswa berdasarkan tingkat semesternya dengan rincian bahwa mahasiswa semester II memiliki rata-rata sebesar 3,02 dengan kategori Baik; semester IV memiliki rata-rata sebesar 3,14 dengan kategori Baik; semester VI memiliki rata-rata sebesar 3,34 dengan kategori Baik; semester VIII memiliki ratarata sebesar 3,43 dengan kategori Baik. Berdasarkan deskripsi data tersebut, maka diketahui bahwa sikap entrepreneur mahasiswa semester VIII adalah yang terbaik dengan rata-rata sebesar 3,43 dengan kategori Baik. Deskripsi data dipertegas dalam sajian gambar di bawah ini.

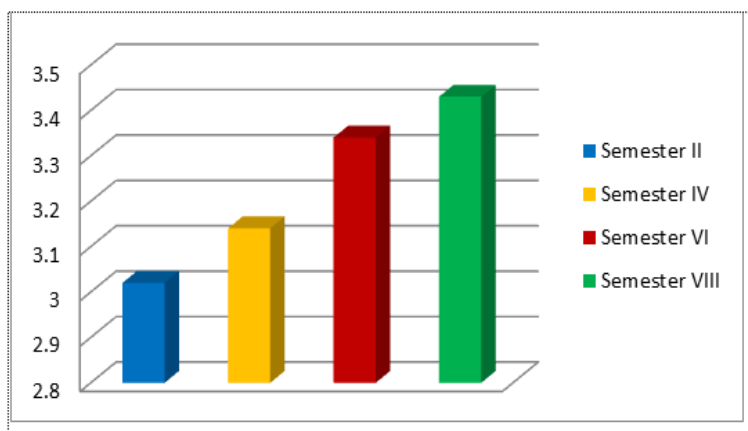

Gambar 2. Rata-rata sikap entrepreneur mahasiswa

Data sikap entrepreneur mahasiswa dianalisis menggunakan statistik parametrik untuk mengetahui signifikansi hubungan antara tingkat semester mahasiswa dengan sikap entrepreneur. Uji statistik yang digunakan adalah uji korelasi product moment $\left(\mathrm{r}_{\mathrm{xy}}\right)$. Hasil uji korelasi product moment $\left(\mathrm{r}_{\mathrm{xy}}\right)$ tentang hubungan antara tingkat semester mahasiswa dengan sikap kewirausahaan (entrepreneur) disajikan pada tabel 5 berikut: Tabel 5. Uji korelasi product moment $\left(\mathrm{r}_{\mathrm{xy}}\right)$

\begin{tabular}{|c|c|c|}
\hline Koefisien Korelasi & N & Sig. (2-tailed) \\
\hline 0,388 & 56 & 0,003 \\
\hline
\end{tabular}

Hasil uji korelasi product moment $\left(\mathrm{r}_{\mathrm{xy}}\right)$ menunjukkan bahwa nilai signifikansi sebesar 0,003 lebih kecil dari nilai alpha pengujian $0,05(<0,05)$, sehingga $\mathrm{H}_{0}$ ditolak dan $\mathrm{H}_{1}$ diterima yang artinya bahwa ada hubungan yang positif dan signifikan antara tingkat semester mahasiswa dengan sikap entrepreneur. Nilai koefisien korelasi sebesar 0,388 yang artinya hubungan bersifat lemah atau rendah.
Hasil penelitian yang menunjukkan ada hubungan yang positif dan signifikan antara tingkat semester mahasiswa dengan sikap entrepreneur. Secara matematis diketahui bahwa sikap entreprenur mahasiswa semester VI dan VIII lebih baik dibandingkan semester II dan IV. Mahasiswa semester VI dan VIII pernah menempuh matakuliah kewirausahaan. Hasil penelitian ini menunjukkan bahwa sikap entrepreneur tidak terlepas dari faktor pengetahuan dan wawasan mahasiswa dalam bidang wirausaha (entrepreneur). Pengetahuan dan wawasan kewirausahaan (entrepreneur) dapat diperoleh dari berbagai sumber seperti pembelajaran dan pengalaman sehari-hari. Penguatan pengetahuan dan wawasan dapat dilakukan melaluli pengalaman dalam pembelajaran matakuliah kewirausahaan. Pembelajaran kewirausahaan akan memberikan penguatan pengetahuan secara terstruktur dan sistematis kepada mahasiswa, sehingga terbentuk mindset dan keterampilan sebagai seorang entrepreneur. Pada akhirnya pengalaman belajar akan merubah persepsi, sikap dan prilaku mahasiswa untuk memiliki motivasi yang kuat dalam menciptakan kreativitas dan inovasi demi terwujudnya wirausaha handal (Suryana, 2014; Sumarsono, 2009). Pendapat lainnya disampaikan bahwa perananan pembelajaran kewirausahaan sangat strategis karena mampu memfasilitasi keterampilan berwirausaha (entrepreneur) dan kecakapan hidup (life skill) secara terintegrasi, terstruktur, sistematis, kontinyu dan kolaboratif dengan pendidikan keluarga. Akhirnya lulusan memiliki kompetensi dan keterampilan sebagai insan yang mandiri dalam persaingan global, kebudayaan dan masyarakat sekitarnya (Fatimah, 2013; Nurseto, 2010; Wahyuni dan Hidayati, 2017; Sonhadji, 2006).

Pembelajaran

kewirausahaan (entrepreneur) dapat membangun mainset dan life skill lulusan secara komprehensif, sehingga memiliki kemandirian dalam menjalankan hidup. Hal ini sesuai dengan pendapat Thomas (dalam Fatimah, 2013) bahwa pembelajaran kewirausahaan (entrepreneur) memfasilitasi mahasiswa untuk mampu menggabungkan kreativitas, 
inovasi, keahlian manajemen peluang, keberanian menghadapi resiko dan kerja keras untuk membentuk dan memelihara usaha baru. Pembelajaran berbasis entrepreneurship di perguruan tinggi nantinya akan meluluskan alumni dengan kompetensi yaitu keratif, inovatif, produktif, percaya diri; berani mengambil resiko; memiliki jiwa kepemimpinan; yakin; tidak ketergantungan; optimis; tekun; kerja keras (Hantoro, 2005; Nugroho, 2009). Oleh sebab itu, empat pilar pendidikan sangat relevan dalam menjalankan pembelajaran berbasis entrepreneurship yaitu Learning to know (belajar untuk mengetahui kewirausahaan), learning to do (belajar untuk melakukan kegiatan wirausaha), learning to be (belajar untuk menjadi entrepreneur), dan learning to live together (belajar untuk bersama dengan yang lainnya dalam interaksi sosial saat berwirausaha) (Supeni dan Efendi, 2017; Rosmiati, 2015).

Hasil penelitian menunjukkan bahwan nilai koefisien korelasi 0,388 yang artinya hubungan antara tingkat semester mahasiswa dengan sikap entrepreneur bersifat lemah atau rendah. Hal ini menunjukkan bahwa pengembangan sikap entrepreneur belum maksimal, sehingga diperlukan adanya peningkatan kuantitas dan kualitas pembinaan kewirausahaan kepada mahasiswa. Pembelajaran kewirausahaan yang diperoleh mahasiswa Pendidikan Biologi selama ini masih terbatas hanya 2 SKS, sehingga perlu dilakukan strategi lain untuk memberikan penguatan pengetahuan kewirausahaan yang komprehensif. Salah satunya adalah melalui integrasi nilai-nilai entrepreneur dalam matakuliah Biologi yang memiliki materi relevan seperti Mikrobiologi dan Bioteknologi. Pembelajaran biologi berbasis entrepreneur yang disingkat bioentrepreneurship sangat relevan untuk diterapkan di perguruan tinggi sesuai dengan hakekat pembelajaran biologi yang mengutamakan discovery, inquiry, constructivism, contextual dan science, technology, and society. Pembelajaran bioentrepreneurship adalah pembelajaran kontekstual yang memfasilitasi pengalaman belajar dalam mengamati, mengidentifikasi, mengkaji, menganalisis dan memanfaatkan biodiversitas dan bioteknologi untuk menciptakan produk yang mengandung nilai ekonomi. Pembelajaran bioentrepreneurship diharapkan dapat memberikan pengalaman belajar kepada mahasiswa untuk menjadi academic entrepreneurship yang memiliki nilai-nilai seperti mandiri, kreatif, berani mengambil resiko, berorientasi pada tindakan, kepemimpinan, kerja keras, jujur, disiplin, inovatif, tanggung jawab, kerjasama, pantang menyerah, komitmen, realistis, rasa ingin tahu, komunikatif, dan motivasi kuat untuk sukses. Oleh sebab itu, pada pembelajaran bioentrepreneurship, selain untuk menjadikan mahasiswa menguasai kompetensi (materi) yang ditargetkan, juga dirancang dan dilakukan untuk menjadikan mahasiswa mengenal, menyadari/peduli, dan menginternalisasi nilai-nilai kewirausahaan dan menjadikannya perilaku dan keterampilan hidupnya (life skill) (Agusti, 2017; Sudarisman, 2015; Kristianti, 2012; Ulwiyah, 2010; Priyanto, 2009).

\section{KESIMPULAN}

Berdasarkan hasil penelitian dan pembahasan di atas, maka dapat disimpulkan bahwa (1) sikap entrepreneur mahasiswa semester VIII adalah yang terbaik dengan rata-rata sebesar 3,43 dengan kategori Baik. Hal itu sesuai dengan data sikap entrepreneur yang menunjukkan bahwa mahasiswa semester II memiliki rata-rata sebesar 3,02 dengan kategori Baik; semester IV memiliki rata-rata sebesar 3,14 dengan kategori Baik; semester VI memiliki rata-rata sebesar 3,34 dengan kategori Baik; semester VIII memiliki rata-rata sebesar 3,43 dengan kategori Baik; (2) Ada hubungan yang signifikan antara tingkat semester mahasiswa dengan sikap entrepreneur. Hal itu sesuai dengan hasil uji korelasi product moment $\left(\mathrm{r}_{\mathrm{xy}}\right)$ menunjukkan bahwa nilai signifikansi sebesar 0,003 lebih kecil dari nilai alpha pengujian $0,05(<0,05)$.

\section{DAFTAR PUSTAKA}

Agusti, E. 2017. Pengembangan Handout Pembelajaran IPA berbasis Entrepreneurship untuk Siswa Kelas XI Tata Niaga di Sekolah Menengah Kejuruan. Artikel Skripsi Fakultas Keguruan dan Ilmu Pendidikan 
Universitas jambi (Tidak diterbitkan).

Arikunto. 2006. Prosedur Penelitian (Suatu

Pendekatan Praktik). Jakarta:

Rineka Cipta.

Fatimah, S. 2013. Menumbuhkan Jiwa Wirausaha Muda dalam Pembelajaran Ekonomi. CRIKSETRA: Jurnal Pendidikan dan Kajian Sejarah . Volume 3 Nomor 4: 1-9.

Hantoro, S. 2005. Kiat Sukses Berwirausaha, Yogyakarta: Adicita Karya Nusa.

Ibnu. S. 2003. Dasar-Dasar Metodologi Penelitian. Malang: Universitas Negeri Malang.

Kristianti, E.A., Bintari, S.H., Ridlo, S. 2012. Pengembangan Perangkat Pembelajaran Bioentrepreneurship Pembuatan Makanan dari Limbah Cair Pengolahan Kedelai. Journal of Innovative Science Education. Volume 1 Nomor 1: 112-118.

Nugroho, R. 2009. Memahani Latar Belakang Pemikiran Entrepreneurship Ciputra. Jakarta: Elex Media Komputindo.

Nurseto, T. 2010. Pendidikan berbasis

Entrepreneur. Jurnal Pendidikan Akuntansi Indonesia, Volume VIII Nomor 2: 52 - 59

Prasetyo, 2009. Membangun Karakter Wirausaha melalui Pendidikan Berbasis Nilai dalam Program Pendidikan Non Formal. http://blog.uny.ac.id/iisprasetyo.

Primandaru, N. 2017. Analisis Faktor-Faktor Yang Berpengaruh Pada Minat Berwirausaha Mahasiswa. Jurnal Economia. Volume 13 Nomor 1: 6878.

Priyanto, S. 2009. Mengembangkan Pendidikan Kewirausahaan di Masyarakat. Jurnal PNFI. Volumen 1 Nomor 1: 57-82.

Rosmiati, D.T.S. 2015. Sikap, Motivasi, dan Minat Berwirausaha Mahasiswa. JMK, Volume 17, Nomor 1: 21-30.

Singarimbun, M. 2006. Metode Penelitian Survai (Edisi Revisi). Jakarta Barat: Pustaka LP3ES Indonesia.
Sonhadji, A. 2006. Manajemen Berbasis Sekolah dan Masyarakat. Jakarta: Nimas Multima.

Sudarisman, S. 2015. Memahami hakikat dan Karakteristik Pembelajaran Biologi dalam Upaya Menjawab Tantangan Abad 21 serta Optimalisasi Implementasi Kurikulum 2013. Jurnal Florea. Volume 2 Nomor 1: 29-35.

Sudijono. A. 2009. Pengantar Statistik Pendidikan. Jakarta: Raja Grafindo Persada.

Sumarsono, 2009. Wirausaha. Bandung: Mandar Maju.

Supeni, R.E \& Efendi, M. 2017. Minat Mahasiswa dalam Berwirausaha Perguruan Tinggi Swasta di Kabupaten Jember. Prosiding Seminar Nasional dan Call For Paper Ekonomi dan Bisnis. Jember, 27-28 Oktober 2017: 449-463.

Ulwiyah, N. 2010. Integrasi Nilai-nilai Entrepreneurship Dalam Proses Pembelajaran di Kelas Guna Menciptakan Academic Entrepreneur Berkarakter. Makalah pada Program Studi PGMI, Fakultas Agama Islam, Unipdu Jombang (Tidak diterbitkan).

Wahyuni, W.R \& Hidayati, W. 2017. Peran Sekolah dalam Membentuk Keterampilan Wirausaha Berbasis Tauhid di SD Entrepreneur Muslim Alif-A Piyungan Bantul Yogyakarta. MANAGERIA: Jurnal Manajemen Pendidikan Islam. Volume 2 Nomor 2: 359-377. 